\title{
Cultivation of the microalga thalassiosira weissflogii to feed the rotifer brachionus rotundiformis
}

\begin{abstract}
The microalga Thalassiosira weissflogii (Grunow) Fryxell and Hasle, 1977 was cultivated to find its adequate concentration to feed the rotifer Brachionus rotundiformis Tschugunoff, 1921. The microalgae and rotifers were reared separately; microalgae cultures used Guillard and Ryther F/2 medium in transparent $19 \mathrm{~L}$ plastic bottles, yielding $16 \mathrm{~L}$ of the useful crop; agitation was kept constant by bubbling compressed air filtered at $1 \mu \mathrm{m}$; lighting was continuous through six white daylight fluorescent lamps. The temperature ranged between $23.1^{\circ}$ and $24.9^{\circ} \mathrm{C}$, and disinfection was with commercial sodium hypochlorite at $5 \%$, which was eliminated at a rate of $0.06 \mathrm{~g} \cdot \mathrm{L}^{-1}$ sodium thiosulfate, then the $\mathrm{F} / 2$ nutrients were added. Rotifers in $15 \mathrm{~L}$ plastic containers were fed daily on $T$. weissflogii at $2.469 \times 10^{5} \mathrm{cells} \cdot \mathrm{mL}^{1}$; Crops were harvested every third day $(48 \mathrm{~h})$. T.weissflogii cultures maintained for $48 \mathrm{~h}$ achieved concentrations adequate to feed these rotifers.
\end{abstract}

Keywords: Cultivation, Food of rotifers, Nutrient addition, Microalgae density, Thalassiosira weissflogii
Volume 6 Issue 5 - 2017

\author{
AA Ortega Salas,' Pedro Flores Nava ${ }^{2}$ \\ 'Unidad Acad mica Mazatl n Instituto de Ciencias del Mar y \\ Limnolog a Mexico \\ ${ }^{2}$ Facultad de Ciencias del Mar Universidad Aut noma de Sinaloa \\ Mexico
}

\begin{abstract}
Correspondence: AA Ortega Salas Unidad Acad mica Mazat n Instituto de Ciencias del Mar y Limnolog a UNAM Calzada
\end{abstract} Joel M Mexico, Email orstal@ola.icmyl.unam.mx

Received: November 09, 2017 | Published: December 07, 2017

\section{Introduction}

Rotifers are a useful source of food in aquaculture ${ }^{1}$ Their nutritional content is enhanced if they are fed on algae, particularly in terms of vitamins and essential fattyacids. The algal genera most frequently used for this purpose are Chaetoceros, Thalassiosira, Isochrysis, Nannochloropsis and Tetraselmis. ${ }^{2}$ The diatom T. weissflogii (size $6-15 \mu \mathrm{m} \times 20 \mu \mathrm{m}$ ) is used as food for shrimp and in the production of bivalve larvae. This alga is considered by several hatcheries to be the best for growing shrimp larvae since it is a rich source of eicosapentaenoic acid (EPA) and docosahexaenoic acid DHA, essentials for growth and development of marine organisms. ${ }^{3-6}$

Emmerson $^{3}$ reported that Penaeus indicus larvae at the zoea 1 stage ingested T.weissflogii at a rate of $2.5 \times 10^{3}$ cells $\bullet$ ind $^{-1} \bullet h^{-1}$.

In this work, the microalga Thalassiosira weissflogii (Grunow) Fryxell and Hasle, 1977 was cultivated under conditions that sought to improve its production rate and to achieve a concentration adequate to feed the rotifer Brachionus rotundiformis Tschugunoff, 1921under laboratory conditions.

\section{Materials and methods}

The diatom T.weisflogii (collection keyTH-W-1) was obtained from the collection of the Department of Aquaculture, Center for Scientific Research and Higher Education, Ensenada, Baja California. Culture used F/2 medium ${ }^{5}$ with twice metasilicate. Seawater was pumped from the Bay of Mazatlán and passed through a filter system in series, with progressive particle retention of 10,5 and $1 \mu \mathrm{m}$; an additional activated carbon filter removed organic compounds.

The temperature ranged between 23.1 and $24.9 \pm 0.52^{\circ} \mathrm{C}$. The water was disinfected with $1 \mathrm{~mL} \cdot \mathrm{L}^{-1}$ commercial sodium hypochloriteat $5 \%$, at least $24 \mathrm{~h}$ before use. Free chlorine residues were removed with $0.06 \mathrm{~g}$ of sodium thiosulfate per liter of water, accelerating the process of neutralization by vigorous shaking aeration for 20 to 25 minutes. Subsequently, the absence of free chlorine was confirmed by the traditional colorimetric technique using a commercial kit with ortho-toluidineasa indicator. Nutrient solutions were added until the F formulation was achieved.
In order to have the required daily amount of microalgal biomass, $T$. weissflogii cultures were maintained in $\mathrm{F}$ medium for $48 \mathrm{~h}$ to obtain adequate concentrations of microalgae to feed rotifers. Cultures were performed in clear plastic bottles of 19L, with $16 \mathrm{~L}$ of a useful crop; stirring was kept constant by bubbling with filtered compressed airat 1 micron. This served to keep the algae in suspension, and encouraged mixing, which was intended to accelerate the exchange of gases between the culture medium and the atmosphere, removing excess photosynthetic oxygen and facilitating the dissolution of $\mathrm{CO}_{2}$ in the medium. Lighting was continuous through six white day light fluorescent lamps.

Before rotifers were fed, the adequate cell concentration of the $T$. weissflogii was verified by direct counts in a compound microscope using a hemocytometer $0.1 \mathrm{~mm}$ deep, equipped with a Neubauer rule. Every $24 \mathrm{~h}$, samples of the culture were taken to check their condition and their stability by optical density reading sina Hach DR 5000 spectrophotometerata wavelength of $550 \mu \mathrm{m}$. The viability of the culture was monitored by $\mathrm{pH}$ readings of each culture vessel with a portable potentiometer rCHEK-MITE Corning model $\mathrm{pH}-10$, precalibrated with buffers of 7.0 and10.0units; this was done in order to prevent high $\mathrm{pH}$ values due to a rapid use of bicarbonates, leading to a limitation of substrates for photosynthesis and hence to maturation of the crop before harvest time, or a switch to the stationary phase or death. Cells were counted at 24 and $48 \mathrm{~h}$ and were harvested at $48 \mathrm{~h}$ when the cultures were in the exponential growth phase.

\section{Results}

An initial concentration of $0.101 \times 10^{5} \mathrm{cells} \cdot \mathrm{mL}^{-1}$ increased to $0.723 \times 10^{5} \mathrm{cells} \cdot \mathrm{mL}^{-1}$ at $24 \mathrm{~h}$ and to $2.469 \times 10^{5} \mathrm{cells} \cdot \mathrm{mL}^{-1}$ at $48 \mathrm{~h}$, the end of each set of cultures (Table 1). Crops were harvested every third day. These cell concentrations indicated that 2.854 T.weissflogii cell divisions had occurred in the first $24 \mathrm{~h}$, and a further 1.772 at $48 \mathrm{~h}$, a total of 4.626 at the time of harvesting.

The cultures from which the samples were obtained to estimate the weight of the microalgae had a cell concentration of $1.903 \times 10^{5}$ cells $\cdot \mathrm{mL}^{-1}$; these crops produced at the time of harvest at 48 ha dry biomass of $114.131 \mathrm{mg} \cdot \mathrm{mL}^{-1}$, and the organic content 
was $66.681 \mathrm{mg} \cdot \mathrm{mL}^{-1}$. With the above values, the unit dry biomass is estimated at $603.363 \pm 52.896 \mathrm{pg} \cdot \mathrm{cells}^{-1}$, and unit organic content of $352.801 \pm 29.697 \mathrm{pg} \cdot$ cells $^{-1}$, and $58511 \%$ of the dry weight was organic matter (Table 2).

B.rotundiformis cultures were maintained at a temperature of $26.6 \pm 0.771$ and $27.8 \pm 0.830^{\circ} \mathrm{C}$. The $\mathrm{pH}$ values in all recipients ranged from 7.85 to 8.19 , with a mean value of 8.03 . Average daily rotifer density obtained was $131.5 \pm 14.153 \mathrm{rot} \cdot \mathrm{mL}^{-1}$; this amount was enough to feed three stages of mysislarvae of Litopenaeus vannamei (Boone, 1931). $\mathrm{pH}$ values increased from 8.094 at $0 \mathrm{~h}$ to 9.084 at $48 \mathrm{~h}$. The optical density increased from 0.044 at $0 \mathrm{~h}$ to 0.110 at $48 \mathrm{~h}$.

Table I Culture of T.weissflogii: cell concentration (CC, $\left.10^{5} \mathrm{cells} \cdot \mathrm{mL}^{-1}\right), \mathrm{pH}$ and optical density (OD).Values: average \pm standard deviation

\begin{tabular}{llll}
\hline Hours & CC & PH & OD \\
\hline 0 & $0.101 \pm 0.008$ & $8.094 \pm 0.253$ & $0.044 \pm 0.003$ \\
24 & $0.723 \pm 0.164$ & $8.422 \pm 0.171$ & $0.062 \pm 0.004$ \\
48 & $2.469 \pm 0.522$ & $9.084 \pm 0.183$ & $0.110 \pm 0.006$ \\
\hline
\end{tabular}

Table 2 Thalassiosira weissflogii sampled after $48 \mathrm{~h}$ culture for weight determinations: cell concentration $\left(C C, 10^{5} \mathrm{cells} \cdot \mathrm{mL}^{-1}\right)$, dry weight (DW) and organic weight $(\mathrm{OW})$ inmg $\cdot \mathrm{mL}^{-1}$, dry weight per unit (DWU) and organic weight unit(OWU) pg.cells $\mathrm{s}^{-1}$, percentage of organic matter in the dry weight(OW/ DW).Values: Average \pm standard deviation

\begin{tabular}{|c|c|c|c|c|c|}
\hline CC & DW & OW & DWU & OWU & OWIDW \\
\hline $10^{5}$ cells $\cdot \mathrm{mL}^{-1}$ & $\mu g \cdot \mathrm{mL}^{-1}$ & $\mu g \cdot \mathrm{mL}^{-1}$ & $\mathrm{Pg} \cdot$ cells $^{-1}$ & $\mathrm{Pg} \cdot$ cells $^{-1}$ & $\%$ \\
\hline $1.903 \pm 0.171$ & || $4.131 \pm 6.645$ & $66.681 \pm 2.200$ & $603.363 \pm 52.896$ & $352.801 \pm 29.692$ & $58.511 \pm 1.687$ \\
\hline
\end{tabular}

\section{Discussion}

Bermúdez-Lizárraga ${ }^{1}$ also used T. weissflogii to feed rotifers, but the present study has confirmed that after culture for $48 \mathrm{~h}$ under the conditions described here, the crop is of sufficient concentration to feed rotifers and larvae of shrimp.

Flores-Nava ${ }^{4}$ found that the density of T.weissflogii supplied to zoe a larvae of L.vannamei did not influence the growth, survival, and development of the larvae.

The diatom T.pseudonana (Cleve, 1873) is the only diet that has been found to produce rotifers with the required complement of $n 3$ polyunsaturated fatty acids suitable for larval fish rearing, ${ }^{6}$ but here we have used $T$. weissflogii to feed rotifers with good results.

\section{Conclusion}

T.weissflogiicultures maintained for $48 \mathrm{~h}$ achieved adequate concentrations to feed the rotifer $B$. rotundiformis which later can be used to feed shrimp larvae.

\section{Acknowledgements}

To the Faculty of Marine Science of the Autonomous University of Sinaloa for provision of equipment and laboratory facilities, and to Dr. Pablo Piña Valdez, Director of the Master of Science thesis of the second coauthor. Thankful to Dr. Ann Grant help us to write this paper.

\section{Conflicts of interest}

None.

\section{References}

1. Bermudez Lizárraga JF. Evaluación de Brachionusrotundiformis como alimento vivo para las larvas de Litopenaeus vannamei. Tesis de Maestría en Ciencia en pesquerías sustentables. Instituto Tecnológico de Mazatlá Mazatlán, Sinaloa, México. 2009;pp.55.

2. Duerr EOA Molnar, V Sato. Cultured microalgae as aquaculture feeds. Journal of Marine. Biotechnology. 1998;7:65-70.

3. Emmerson WD. Ingestion, growth and development of Penaeusindicus larvae as a function of Thalassiosira weissflogii cells concentration. Marine Biology. 1980;58(1):65-73.

4. Flores Nava P. Crecimiento, desarrollo y supervivencia de larvas zoea de Litopenaeus vannamei alimentadas con Thalassiosira weissflogii. Tesis de Licenciatura Biólogo Pesquero. Facultad de Ciencias del Mar. UAS, Mazatlán, Sinaloa, México. 2008;pp.41

5. Guillard RRL, Ryther JH. Studies of marine planktonic diatoms, Cyclotella nana (Hustedt) and Detonula confervacea (Cleve) Can J Microbiology. 1962;8:229-239.

6. White JNC, Nagata WD. Carbohydrate and fatty acid composition of the rotifer, Brachionus plicatilis, fed monospecific diets of yeast or phytoplankton. Aquaculture. 1990;89(3-4):263-272. 